\title{
Determining Critical Soil pH for Sunflower Production
}

\author{
Apurba Sutradhar, ${ }^{1}$ Romulo P. Lollato, ${ }^{1}$ Katy Butchee, ${ }^{2}$ and Daryl B. Arnall ${ }^{1}$ \\ ${ }^{1}$ Department of Plant and Soil Sciences, Oklahoma State University, Stillwater, OK 74078, USA \\ ${ }^{2}$ Western Oklahoma State College, 2801 N. Main, Altus, OK 73521, USA \\ Correspondence should be addressed to Daryl B. Arnall; b.arnall@okstate.edu
}

Received 7 April 2014; Accepted 2 June 2014; Published 6 July 2014

Academic Editor: Allen Barker

Copyright (C) 2014 Apurba Sutradhar et al. This is an open access article distributed under the Creative Commons Attribution License, which permits unrestricted use, distribution, and reproduction in any medium, provided the original work is properly cited.

Soil acidity has become a major yield-limiting factor in cropping systems of the Southern Great Plains, in which winter wheat (Triticum aestivum L.) is the predominant crop. Sunflower (Helianthus annuus L.) is a strong rotational crop with winter wheat due to its draught and heat tolerance. However, the effects of low soil pH on sunflower productivity have not been explored. The objective of this study was to determine the critical soil $\mathrm{pH}$ and aluminum concentration $\left(\mathrm{Al}_{\mathrm{KCl}}\right)$ for sunflower. Sunflower was grown in a randomized complete block design with three replications of a $\mathrm{pH}$ gradient ranging from 4.0 to 7.0 at three locations with varying soil types. Soil $\mathrm{pH}$ was altered using aluminum sulfate $\left(\mathrm{Al}_{2}\left(\mathrm{SO}_{4}\right)_{3}\right)$ and hydrated lime $\left(\mathrm{Ca}(\mathrm{OH})_{2}\right)$. Plant height, vigor, and survivability were all negatively affected by soil acidity. Sunflower yield was reduced by $10 \%$ at or below soil $\mathrm{pH} 4.7$ to 5.3 dependent upon location and soil type. Levels of $\mathrm{Al}_{\mathrm{KCl}}$ above $6.35 \mathrm{mg} \mathrm{kg}^{-1}$ reduced seed yield by $10 \%$ or greater. We concluded that sunflower may serve as a better rotational crop with winter wheat under acidic conditions when compared to other adaptable crops.

\section{Introduction}

The southern Great Plains of the United States is one of the most intensive winter wheat (Triticum aestivum L.) production regions in the world. However, the increasing adoption of no-tillage practices in recent years led to greater crop diversification and, consequently, alternative summer crops are being grown as part of crop rotation systems [1]. Sunflower (Helianthus annuus L.) arises as a valuable option as rotational crop with no-till winter wheat for its ability to tolerate warm and relatively dry climates, which are typical characteristics of summer periods in the region. Summer periods in Oklahoma are characterized by high evaporative demand and low precipitation; thus the crops are often subjected to drought stress [2]. Thus, strategies to mitigate the effects of water deficit such as choosing a drought tolerant crop are warranted for summer crops in the region.

Although acidity is not a natural problem for most agricultural soils in Oklahoma, intensive monocropping wheat production led to soil acidification in many Oklahoma fields. A review of soil test results in 1997 by the Potash and Phosphate institute concluded that $37 \%$ of the tested samples in Oklahoma had soil pH of less than 6.0 [3]. Furthermore, Zhang and McCray [4] reported that $23.6 \%$ of 68,000 soil samples received by the Oklahoma State University Soil, Water, and Forage Analytical Laboratory had soil pH of less than 5.5 during the period of 2004 to 2008 . The observed lower soil $\mathrm{pH}$ values resulted from heavy use of ammonia/ammonium based nitrogen $(\mathrm{N})$ fertilizers, which led to acidic conditions by the net positive balance of hydrogen ions in the soil $[5,6]$. Oxidation of $\mathrm{NH}_{4}{ }^{+}$to $\mathrm{NO}_{3}{ }^{-}$generates $\mathrm{H}^{+}$ which results in lower soil $\mathrm{pH}[7,8]$. This acidification is further worsened by the removal of basic cations through the harvesting of forage and grain [9].

Decreased soil $\mathrm{pH}$ has the aggravating consequence of increased solubility of aluminum (Al). Toxic $\mathrm{Al}$ is associated with soil $\mathrm{pH}$ and as soil $\mathrm{pH}$ decreases, solubility of $\mathrm{Al}$ increases. In extreme acidic soils in Oklahoma, $\mathrm{Al}$ toxicity is one of the major causes of crop failure [10], as micromolar concentrations of $\mathrm{Al}$ can be toxic for many plants [11]. Increased $\mathrm{Al}$ concentration primarily inhibits root elongation and decreases plants' ability to explore soil for moisture and nutrients [12]. Decreased root elongation is then followed by an inhibition of DNA synthesis that might result in reduced 
seedling emergence and shoot growth [13-15]. Therefore, Al toxicity significantly affects growth and yield of many crops.

Winter wheat can tolerate soil pH 5.5 and lower [16, 17], depending on soil and weather characteristics. Also, use of $\mathrm{Al}$ tolerant winter wheat varieties and banding of phosphorus fertilizers has allowed producers to grow winter wheat in unfavorable low $\mathrm{pH}$ conditions $[17,18]$. As winter wheat accounts for approximately $75 \%$ of Oklahoma's cropland [10], many producers do not consider liming in their management practices when soil $\mathrm{pH}$ is below the critical threshold levels for winter wheat. However, sunflower has traditionally been produced on soils with nearly neutral pH (6.5 to 7.5) [19]. Thus, with the integration of sunflower into the rotation system, liming acidic soils may now need to be considered within the farmer's management practices.

The exact quantitative effect of soil $\mathrm{pH}$ on sunflower growth and productivity has not previously been evaluated. Most research relating to soil acidity in the Central Great Plains has focused on winter wheat, while some studies have focused on determining the most acid tolerant varieties of crops $[13,20]$. Determining the effects of a wide range of soil $\mathrm{pH}$ and extractable $\mathrm{Al}$ on sunflower growth and seed yield will be a useful tool for educating producers and agronomists about the importance of liming acid soils. Therefore, the objective of this study was to determine the critical soil $\mathrm{pH}$ and $\mathrm{Al}$ tolerance for sunflower production in Oklahoma.

\section{Materials and Methods}

2.1. Sites. Three field experiments were conducted for the growing seasons of 2009 and 2010, one in a Teller sandy loam (fine-loamy, mixed, active, thermic Udic Argiustolls) at the Cimarron Valley Research Station near Perkins $\left(35^{\circ} 59^{\prime} 23^{\prime \prime} \mathrm{N}\right.$, $97^{\circ} 2^{\prime} 48^{\prime \prime} \mathrm{W}$ ) and another in a Taloka silt loam (fine, mixed, active, thermic Mollic Albaqualfs) at the Eastern Research Station near Haskell $\left(35^{\circ} 49^{\prime} 1^{\prime \prime} \mathrm{N}, 95^{\circ} 39^{\prime} 24^{\prime \prime} \mathrm{W}\right)$; and the third was in a Grant silt loam (fine-silty, mixed, superactive, thermic Udic Argiustolls) at the North Central Research Station near Lahoma $\left(36^{\circ} 23^{\prime} 4^{\prime \prime} \mathrm{N}, 98^{\circ} 6^{\prime} 27^{\prime \prime} \mathrm{W}\right)$, Oklahoma. Initial soil fertility conditions for all three locations are presented in Table 1 .

2.2. Treatments and Experimental Design. Treatments were arranged in a randomized complete block design with $6 \mathrm{~m}$ long and $3 \mathrm{~m}$ wide plots. Treatments were six target soil $\mathrm{pH}$ values ranging from 4.0 to 7.0 (i.e., 4.0, 4.5, 5.0, 5.5, 6.0, and 7.0). All experimental treatments were replicated three times with $4.6 \mathrm{~m}$ alleys at Perkins and Lahoma and $3 \mathrm{~m}$ alleys at Haskell. One composite sample consisting of 15 to 20 soil cores to a depth of $15 \mathrm{~cm}$ was collected from each plot prior to planting. These samples were used to determine the initial soil $\mathrm{pH}$ and plant-available nitrogen $(\mathrm{N})$, phosphorus $(\mathrm{P})$, and potassium $(\mathrm{K})$ concentrations. Soil samples were dried at $60^{\circ} \mathrm{C}$ overnight and ground to pass through a $2 \mathrm{~mm}$ sieve. A $1: 1$ soil : water suspension and glass electrode $\mathrm{pH}$ meter were used to measure soil $\mathrm{pH}$ and buffer index $[21,22]$. Soil nitratenitrogen $\left(\mathrm{NO}_{3}-\mathrm{N}\right)$ and ammonium-nitrogen $\left(\mathrm{NH}_{4}-\mathrm{N}\right)$ were extracted using $1 \mathrm{M}$ potassium chloride $(\mathrm{KCl})$ quantified by a flow injection autoanalyzer (Lachat Instrument, Milwaukee,
Wis, USA). Mehlich 3 solution was used to extract plantavailable $\mathrm{P}$ and $\mathrm{K}$, and the amounts of $\mathrm{P}$ and $\mathrm{K}$ were quantified using a Spectro Ciros inductively coupled plasma (ICP) spectrophotometer $[23,24]$. Initial soil test results were used to calculate $\mathrm{N}, \mathrm{P}$, and $\mathrm{K}$ fertilizer rates and were broadcasted over each trial in 2009 and 2010.

Hydrated lime $\left(\mathrm{Ca}(\mathrm{OH})_{2}\right)$ and aluminum sulfate $\left(\mathrm{Al}_{2}\left(\mathrm{SO}_{4}\right)_{3}\right)$ were applied to obtain target soil $\mathrm{pH}$. To determine the amount of material needed to reach a given target soil $\mathrm{pH}$, a laboratory experiment was conducted in 2009 to develop a response curve, as previously described by Butchee et al. [25]. To perform this laboratory experiment, composite soil samples were collected from all experimental sites to characterize initial site conditions. Subsamples weighing $500 \mathrm{~g}$ were taken from each composite sample and mixed with five incremental rates of $\mathrm{Al}_{2}\left(\mathrm{SO}_{4}\right)_{3}$ and $\mathrm{Ca}(\mathrm{OH})_{2}$. The samples were then wetted and, after two, three, and four weeks, soil $\mathrm{pH}$ of each subsample was measured. These $\mathrm{pH}$ values were plotted as a function of $\mathrm{Ca}(\mathrm{OH})_{2}$ and $\mathrm{Al}_{2}\left(\mathrm{SO}_{4}\right)_{3}$ to produce different response curves for the three studied locations. Equations obtained from the response curves were then solved to determine the amount of $\mathrm{Ca}(\mathrm{OH})_{2}$ and $\mathrm{Al}_{2}\left(\mathrm{SO}_{4}\right)_{3}$ needed to achieve a specific soil $\mathrm{pH}$ for each soil. Depending on the initial values, $\mathrm{Ca}(\mathrm{OH})_{2}$ was applied to raise or $\mathrm{Al}_{2}\left(\mathrm{SO}_{4}\right)_{3}$ was used to lower actual $\mathrm{pH}$ to the target $\mathrm{pH}$ assuming treatments of $15 \mathrm{~cm}$ soil depth. Table 2 lists the initial soil $\mathrm{pH}$ for each location and the amount of $\mathrm{Ca}(\mathrm{OH})_{2}$ and $\mathrm{Al}_{2}\left(\mathrm{SO}_{4}\right)_{3}$ needed to change soil $\mathrm{pH}$ by 1.0 unit. The plots were cultivated to incorporate $\mathrm{Ca}(\mathrm{OH})_{2}$ and $\mathrm{Al}_{2}\left(\mathrm{SO}_{4}\right)_{3}$ down to $20 \mathrm{~cm}$ several months prior to planting.

2.3. Sunflower Management and Relative Yield. Sunflower variety "Triumph S671" was planted in May for all locations for the growing seasons of 2009 and 2010 except for Perkins 2009, where sunflower was planted on June 3rd. A 6200 Monosem vacuum planter was used with a planting rate of 49,400 seeds $\mathrm{ha}^{-1}$. Weeds, insects, and diseases were controlled using commercially available pesticides as needed throughout the growing seasons to ensure these were not limiting factors for crop growth and yield.

2.4. Measurement of Growth Components. Sunflower growth components were measured in 2010 for all three locations. To determine soil $\mathrm{pH}$ effects on crop stand, plant counts were taken from two middle rows of each treatment one to three weeks after emergence. At 7th leaf stage, plant height measurements were taken from five random plants within the two middle rows of each treatment at Perkins and Lahoma. Plant height measurements were taken at 8th leaf stage at Haskell. Normalized Difference Vegetative Index (NDVI) readings were taken from the two middle rows of each treatment when two to five leaves were visible at Perkins and Lahoma with a GreenSeeker (Model 505, NTech Industries, Ukiah, CA). At Haskell, NDVI readings were collected at 8th leaf stage.

The wavelengths of near-infrared (NIR) and red light are $780 \mathrm{~nm}$ and $671 \mathrm{~nm}$, respectively. Healthier plants have higher amount of chlorophyll, thus absorbing more red light and 
TABLE 1: Initial soil fertility conditions at Perkins, Haskell, and Lahoma, Oklahoma. Soil fertility is characterized by extractable sodium (Na), potassium $(\mathrm{K})$, calcium $(\mathrm{Ca})$, magnesium $(\mathrm{Mg})$, aluminum $\left(\mathrm{Al}_{\mathrm{KCl}}\right)$, effective cation exchange capacity (ECEC), and aluminum saturation $\left(\mathrm{Al}_{\text {sat }}\right)$.

\begin{tabular}{lccccccc}
\hline Location & $\mathrm{Na}$ & $\mathrm{K}$ & $\begin{array}{c}\mathrm{Ca} \\
\mathrm{mg} \mathrm{kg}\end{array}$ & $\mathrm{Mg}$ & $\mathrm{Al}_{\mathrm{KCl}}$ & $\begin{array}{c}\mathrm{ECEC} \\
\mathrm{cmolc} \mathrm{kg}^{-1}\end{array}$ \\
\hline Perkins & 11 & 37 & 17 & 5 & 0.9 & 0.28 \\
Haskell & 25 & 9 & 26 & 4 & 29.4 & 0.62 \\
Lahoma & 20 & 13 & 62 & 29 & 0.1 & 31.5 \\
\hline
\end{tabular}

TABLE 2: Initial soil $\mathrm{pH}$ values of each trial-location and amount of hydrated lime and aluminum sulfate required to change soil $\mathrm{pH}$ by 1.0 unit.

\begin{tabular}{lccc}
\hline Location & Initial soil pH & $\begin{array}{c}\text { Hydrated lime } \\
{\left[\mathrm{Mg} \mathrm{ha}^{-1}\right]}\end{array}$ & $\begin{array}{c}\text { Aluminum sulfate } \\
{\left[\mathrm{Mgha}^{-1}\right]}\end{array}$ \\
\hline Perkins & 4.8 & 1.69 & 1.52 \\
Haskell & 5.2 & 4.10 & 2.17 \\
Lahoma & 5.5 & 1.31 & 2.78 \\
\hline
\end{tabular}

reflecting more NIR [26]. Both reflected lights are received by the sensor; and NDVI is calculated as

$$
\mathrm{NDVI}=\left[\frac{(\mathrm{NIR}-\mathrm{Red})}{(\mathrm{NIR}+\mathrm{Red})}\right]
$$

Therefore, healthier plants have higher NDVI values. These values provide a very strong correlation with biomass, plant health, and plant vigor [27].

Number of sunflower heads in the middle two rows of each plot was counted prior to harvest and was then used to calculate percent reduction in number of plants as

Percent reduction of number of heads

$$
=\left[\frac{(\text { Emergence }- \text { number of heads })}{\text { Emergence }}\right] \times 100 \text {. }
$$

2.5. Sunflower Harvest and Relative Yield. Sunflower was hand-harvested on 3 September 2009 at Lahoma and Haskell. Sunflower was not harvested at Perkins in 2009 due to bird pressure. In 2010, sunflower was hand-harvested at all three locations during the second week of August. Sunflower heads were dried to $13 \%$ moisture level and threshed using a Massey Ferguson experimental plot combine and a Kincaid thresher.

In this study, relative yield was used to avoid bias associated with multiple locations and varying growing conditions. Relative yield was expressed as percentage of maximum yield potential for a particular location for a particular year. Relative yield was calculated as

$$
\begin{aligned}
& \text { Relative yield } \\
& =\left[\frac{\text { Actual yield }}{\text { highest yield for that location for a particular year }}\right] .
\end{aligned}
$$

2.6. Soil Sampling and Analyses. Mid-season soil samples were collected yearly to determine actual soil $\mathrm{pH}$. These $\mathrm{pH}$ values were plotted with sunflower yield and growth factors to create linear plateaus for determining critical level. Soil samples were also collected following the 2009 harvest to evaluate soil nutrient status and soil pH. After harvest in 2010, a final set of composite soil samples was collected to determine potassium-chloride-extractable aluminum $\left(\mathrm{Al}_{\mathrm{KCl}}\right)$ and saturated $\mathrm{Al}\left(\mathrm{Al}_{\text {sat }}\right)$ present in the soil. Soil sample management and measuring cations were followed using the procedures as described previously. To determine Al concentration, a $2.0 \mathrm{~g}$ subsample was taken from each composite sample and was extracted with $20 \mathrm{~mL} 1 \mathrm{M} \mathrm{KCl}$. Samples were placed on a shaker for 30 minutes and filtered, and the amount of $\mathrm{Al}$ extracted with $1 \mathrm{M} \mathrm{KCl}$ was quantified using inductively coupled plasma spectrometry (ICP) [24]. Effective cation exchange capacity (ECEC) and saturated $\mathrm{Al}\left(\mathrm{Al}_{\text {sat }}\right)$ were determined using formula (4) and (5), respectively, suggested by Sumner and Miller (1996) [28]:

$$
\begin{gathered}
\operatorname{ECEC}\left(\mathrm{cmol}_{\mathrm{c}} \mathrm{kg}^{-1}\right) \\
=[\mathrm{K}]+[\mathrm{Ca}]+[\mathrm{Mg}]+[\mathrm{Na}]+\left[\mathrm{Al}_{\mathrm{KCl}}\right], \\
\% \mathrm{Al}_{\mathrm{sat}}=\left(\frac{\mathrm{Al}_{\mathrm{KCl}}}{\mathrm{ECEC}}\right) \times 100 .
\end{gathered}
$$

Additional $91 \mathrm{~cm}$ deep soil cores were taken from three plots with target soil $\mathrm{pH}$ of 4.0, 6.0, and 7.0 using a Giddings probe to determine the variation in soil $\mathrm{pH}$ within the profile. Deep soil cores were not collected at Haskell.

2.7. Statistical Analyses. Data were analyzed using SAS 9.3 software of SAS system (Copyright $\odot$ SAS Institute Inc.). PROC LOESS procedure was used to get smoothed nonparametric fit of data. Using this procedure, breakpoints were estimated visually. Piecewise models for the critical points were developed using nonlinear procedure (PROC NLIN). Two linear regression models using PROC REG for an estimated breakpoint were used on the data to generate starting parameters for PROC NLIN procedure. General linear model (PROC GLM) was used for linear least square regression.

\section{Results and Discussion}

3.1. Amendment Effects on Soil pH. A wide range of final soil $\mathrm{pH}$ values was achieved with the application of amendment strategies. In 2010, soil pH ranged from 4.1 to 7.3 at Perkins 


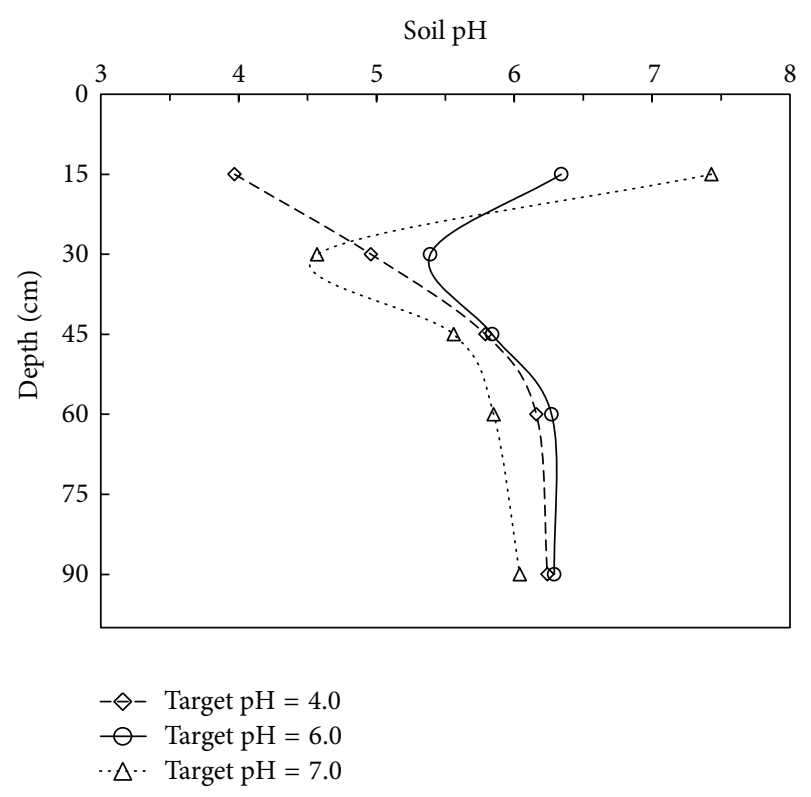

Figure 1: Effect of soil amendments on soil profile $\mathrm{pH}$ at Perkins, Oklahoma, in 2010 for target $\mathrm{pH}$ of 4.0, 6.0, and 7.0. Initial soil $\mathrm{pH}$ on the top $15 \mathrm{~cm}$ soil in 2009 prior to soil amendments application was 4.8 .

(Figure 1), 4.3 to 6.7 at Lahoma (Figure 2), and 3.8 to 6.8 at Haskell that provided a valuable dataset for the analysis of sunflower growth and development on three different soil $\mathrm{pH}$ gradients. The differences between actual and target $\mathrm{pH}$ values varied. In the fine sandy loam at Perkins, soil $\mathrm{pH}$ deviated by $-0.1,+0.3$, and +0.4 from the target soil $\mathrm{pH}$ of $4.0,6.0$, and 7.0 at the $15 \mathrm{~cm}$ depth (Figure 1). Soil pH differed down to a depth of $31 \mathrm{~cm}$, indicating a leaching of amendment materials to deeper profile. In the Grant silt loam at Lahoma, $\mathrm{pH}$ deviated by $+0.2,-1.0$, and +0.6 in the $15 \mathrm{~cm}$ depth from target $\mathrm{pH}$ (Figure 2). However, deeper soil profile analysis indicated that amendment materials did not alter soil $\mathrm{pH}$ at $31 \mathrm{~cm}$. The sandier soil at Perkins allowed leaching of the amendment materials down to approximately $31 \mathrm{~cm}$ depth, whereas, the finer silt loam soil at Lahoma did not. By restricting soil acidity to the upper profile, effects of low $\mathrm{pH}$ on sunflower have been masked by deep root penetration in the Lahoma soil that is typical for sunflower. Nevertheless, this scenario is similar to many Oklahoma acidic soils that are only acidic in the top $15 \mathrm{~cm}$ [29] due to subsequent application of $\mathrm{N}$ fertilizer for wheat production $[16,30]$, which makes the results of this research more practical and applicable in the region.

3.2. Extractable Aluminum Concentration and Aluminum Saturation. Potassium-chloride-extractable Al ranged from $1.19 \mathrm{mg} \mathrm{kg}^{-1}$ to $154 \mathrm{mg} \mathrm{kg}^{-1}$ at Perkins; from $1.0 \mathrm{mg} \mathrm{kg}^{-1}$ to $119 \mathrm{mg} \mathrm{kg}^{-1}$ at Lahoma; and from $1.44 \mathrm{mg} \mathrm{kg}^{-1}$ to $254 \mathrm{mg} \mathrm{kg}^{-1}$ at Haskell (Figure 3(a)). Differences in Al concentrations among locations could have been caused by variation in soil $\mathrm{pH}$ and also by inherent soil chemical characteristics. At similar soil $\mathrm{pH}$, the three different soils contained different $\mathrm{Al}_{\mathrm{KCl}}$ concentrations, with the sandy loam at Perkins generally presenting the highest $\mathrm{Al}_{\mathrm{KCl}}$ concentration at a given soil

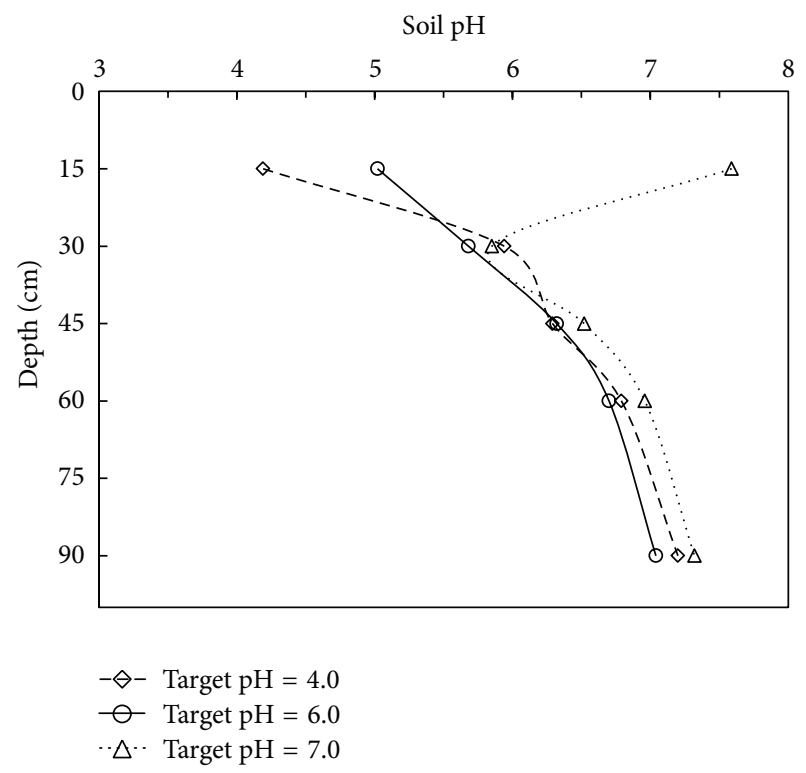

FIGURE 2: Effect of soil amendments on soil profile $\mathrm{pH}$ at Lahoma, Oklahoma, in 2010 for target $\mathrm{pH}$ of 4.0, 6.0, and 7.0. Initial soil pH on the top $15 \mathrm{~cm}$ soil in 2009 prior to soil amendments application was 6.8 .

pH. For example, at $\mathrm{pH} 4.6$, the $\mathrm{Al}$ concentration at Haskell was $35.6 \mathrm{mg} \mathrm{kg}^{-1}$, whereas, at Lahoma it was $58.4 \mathrm{mg} \mathrm{kg}^{-1}$. At similar $\mathrm{pH}$ level, the soil at Perkins resulted in an Al concentration of $96.0 \mathrm{mg} \mathrm{kg}^{-1}$, which indicates that $\mathrm{pH}$ threshold may differ among locations due to the inherent differences among soil types. A significant inverse exponential relationship existed between soil $\mathrm{pH}$ and $\mathrm{Al}_{\mathrm{KCl}}$ at all sites, with $r^{2}$ of 0.93, 0.84, and 0.94 at Perkins, Lahoma, and Haskell, respectively (Figure 3(a)). Potassium-chloride-extractable Al concentrations increased exponentially as soil $\mathrm{pH}$ decreased. For example, at Perkins, a $\mathrm{pH}$ increase from 4.3 to 6.3 decreased $\mathrm{Al}_{\mathrm{KCl}}$ concentration from $131 \mathrm{mg} \mathrm{kg}^{-1}$ to $1.32 \mathrm{mg} \mathrm{kg}^{-1}$. Similar decrease in $\mathrm{Al}$ concentration was observed at Lahoma, where an increase in soil $\mathrm{pH}$ from 4.3 to 6 decreased $\mathrm{Al}$ concentration from $119 \mathrm{mg} \mathrm{kg}^{-1}$ to $1.33 \mathrm{mg} \mathrm{kg}^{-1}$, and at Haskell, where an increase from a $\mathrm{pH}$ of 4.1 to 6.0 decreased $\mathrm{Al}$ concentration from $118 \mathrm{mg} \mathrm{kg}^{-1}$ to $1.44 \mathrm{mg} \mathrm{kg}^{-1}$.

Likewise, $\mathrm{Al}_{\text {sat }}$ decreased exponentially with the increase of soil pH (Figure 3(b)). Results at Haskell and at Perkins were similar to an extent, with $\mathrm{Al}_{\text {sat }}$ ranging from 2.38 to $77 \%$ at Haskell and from 1.67 to $67 \%$ at Perkins. Average $\mathrm{Al}_{\text {sat }}$ across all plots at both sites was near 37\%. At Lahoma, however, $\mathrm{Al}_{\text {sat }}$ values were lower and ranged from 0.85 to $49 \%$, with an average of near $15 \%$ across all plots. As $\mathrm{Al}_{\text {sat }}$ was calculated based on the concentrations of extractable base cations, the higher base cation concentrations at Lahoma (Table 1) most likely led to lower $\mathrm{Al}_{\text {sat }}$ values at this site as compared to both Perkins and Haskell.

The increase in both $\mathrm{Al}_{\mathrm{KCl}}$ and $\mathrm{Al}_{\text {sat }}$ is most likely due to solubilization of soil minerals at the decreased soil $\mathrm{pH}$ and not due to added $\mathrm{Al}$ in the plots that were treated with $\mathrm{Al}_{2}\left(\mathrm{SO}_{4}\right)_{3}$. In a study, Moore and Edwards [31] reported that soil exchangeable $\mathrm{Al}$ was increased due to soil acidification 


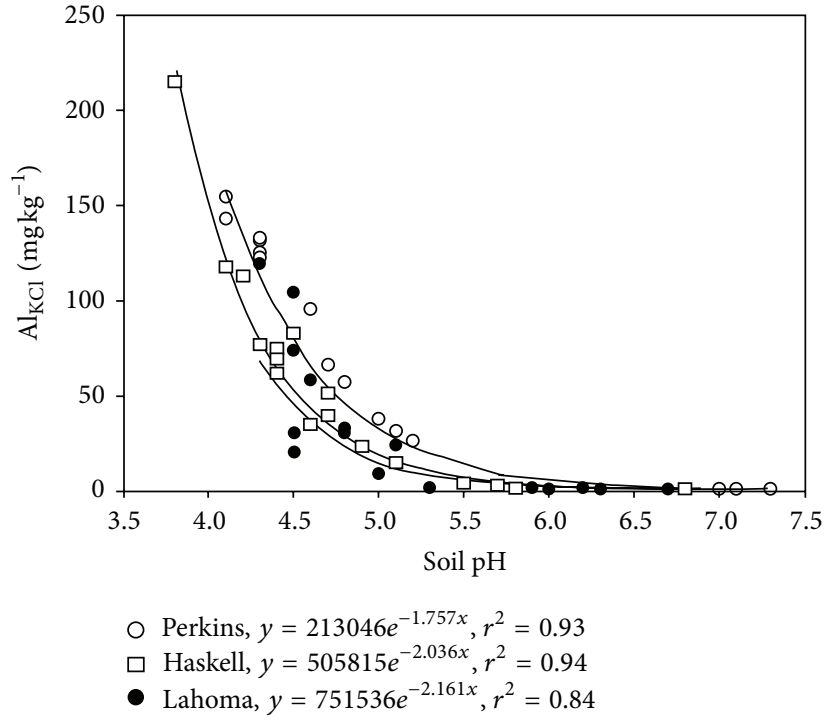

(a)

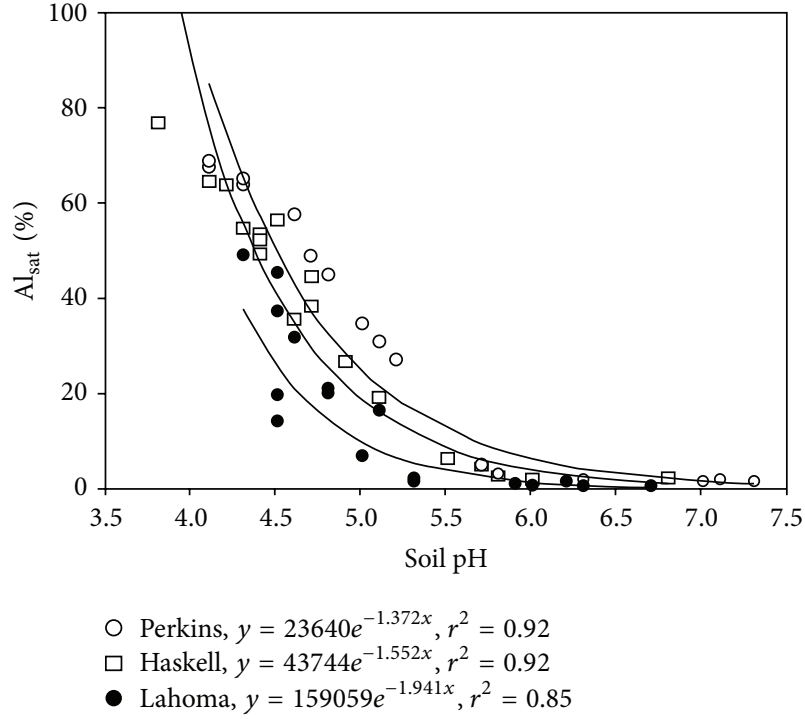

(b)

FIGURE 3: Potassium-chloride-extractable aluminum concentration $\left(\mathrm{mg} \mathrm{kg}^{-1}\right)$ and aluminum saturation (\%) in the soil as the functions of soil pH from a $15 \mathrm{~cm}$ composite soil sample for each treatment at Perkins, Haskell, and Lahoma, Oklahoma (2010).

resulted from ammonium nitrate application. In the same study poultry litter with added Al treatments did not affect soil exchangeable Al. Similar results were found by Warren et al. [32] when comparing $\mathrm{Al}$ treated poultry litter and non$\mathrm{Al}$ treated poultry litter applied to two different types of soils; the relationships between soil $\mathrm{pH}$ and extractable $\mathrm{Al}$ concentration were not affected by litter application.

3.3. Growth Components. Number of sunflower heads per plot at harvest was reduced in low $\mathrm{pH}$ treatments when compared to the plant counts at emergence at all locations in 2010 (Figure 4). This suggested that soil acidity had strong negative impact on sunflower vegetative growth and yield. Percent reduction in number of plants differed among soil types and $\mathrm{pH}$ ranges. Distinct breakpoints appeared for each location when percent reduction in plants was plotted as a function of soil $\mathrm{pH}$. Breakpoints are the $\mathrm{pH}$ values where two fitted functions intersected. These $\mathrm{pH}$ values are considered the transition points (critical values) where high and low reductions in number of plants were differentiated.

Breakpoints generated from nonlinear regression analysis showed that critical $\mathrm{pH}$ for sunflower establishment ranged from 4.0 to 4.8 among all locations. At Perkins, plant mortality was high when soil $\mathrm{pH}$ was less than 4.7 , although, at this $\mathrm{pH}$, stand reduction was approximately only $10 \%$. A further decrease in soil $\mathrm{pH}$ to 4.2 increased percent reduction in number of plants as high as $90 \%$. At Haskell, breakpoint occurred at $\mathrm{pH} 4.0$ where approximately $26 \%$ plant reduction was observed. Below this $\mathrm{pH}$ level, plant mortality was very high, reaching $100 \%$. A $10 \%$ plant loss was calculated when the soil $\mathrm{pH}$ was 6.8 or higher at Haskell. Percent plant reduction was $9 \%$ at $\mathrm{pH} 4.8$ at Lahoma, and decreasing the $\mathrm{pH}$ below that threshold level only resulted in plant mortality near $30 \%$. No sunflower heads were harvested from those plots where
$\mathrm{pH}$ was 3.8 or lower. Differences in critical $\mathrm{pH}$ values in terms of plant mortality among all locations may be functions of the different soil properties such as $\mathrm{Al}$ concentrations. At similar $\mathrm{pH}$ level, $\mathrm{Al}$ concentrations were different in different soil types. Therefore, it was necessary to evaluate the same response also as a function of $\mathrm{Al}$ concentration.

Linear plateau occurred in terms of sunflower establishment when $\mathrm{Al}_{\mathrm{KCl}}$ concentration was $85.4 \mathrm{mg} \mathrm{kg}^{-1}$ at Perkins in 2010, which resulted in plant mortality around 14\% (Figure 4). Using $10 \%$ mortality limit, a threshold point for extractable Al was calculated as $41.0 \mathrm{mg} \mathrm{kg}^{-1}$ for Perkins, using the regression equation derived from PROC NLIN. Plant mortality was linearly correlated to soil $\mathrm{Al}_{\mathrm{KCl}}$ concentration at Haskell, and a $10 \%$ plant reduction was calculated at $\mathrm{Al}_{\mathrm{KCl}}$ concentration of $2.20 \mathrm{mg} \mathrm{kg}^{-1}$, which is a much lower threshold than the one found for Perkins. These results are consistent with the result that a micromolar concentration of $\mathrm{Al}$ can be toxic for plants, as reported by Delhaize and Ryan [11]. It is important to notice that the soil at Haskell originally had greater $\mathrm{Al}_{\mathrm{KCl}}$ concentration than the soil at Perkins (29.4 $\mathrm{mg} \mathrm{kg}^{-1}$ versus $0.90 \mathrm{mg} \mathrm{kg}^{-1}$, Table 1) which may have resulted in higher $\mathrm{Al}$ saturation (percent of exchange sites occupied by $\mathrm{Al}$ over the total exchange sites occupied by base cations) and therefore greater plant reduction across the whole experiment. Reduction of number of plants was not strongly related to soil $\mathrm{Al}_{\mathrm{KCl}}$ at Lahoma, with percent reduction in number of plants rarely surpassing $20 \%$. The very high effective cation exchange capacity (ECEC) of the Grant silt loam at Lahoma probably reduced the Al saturation; therefore, even when $\mathrm{Al}$ concentration was high, its effects probably were amended by the high base cation concentration in the soil. Thus, the contrasting results in $\mathrm{Al}_{\mathrm{KCl}}$ breakpoint threshold between locations may be a function of the different inherent soil chemical properties. Even soils with high 

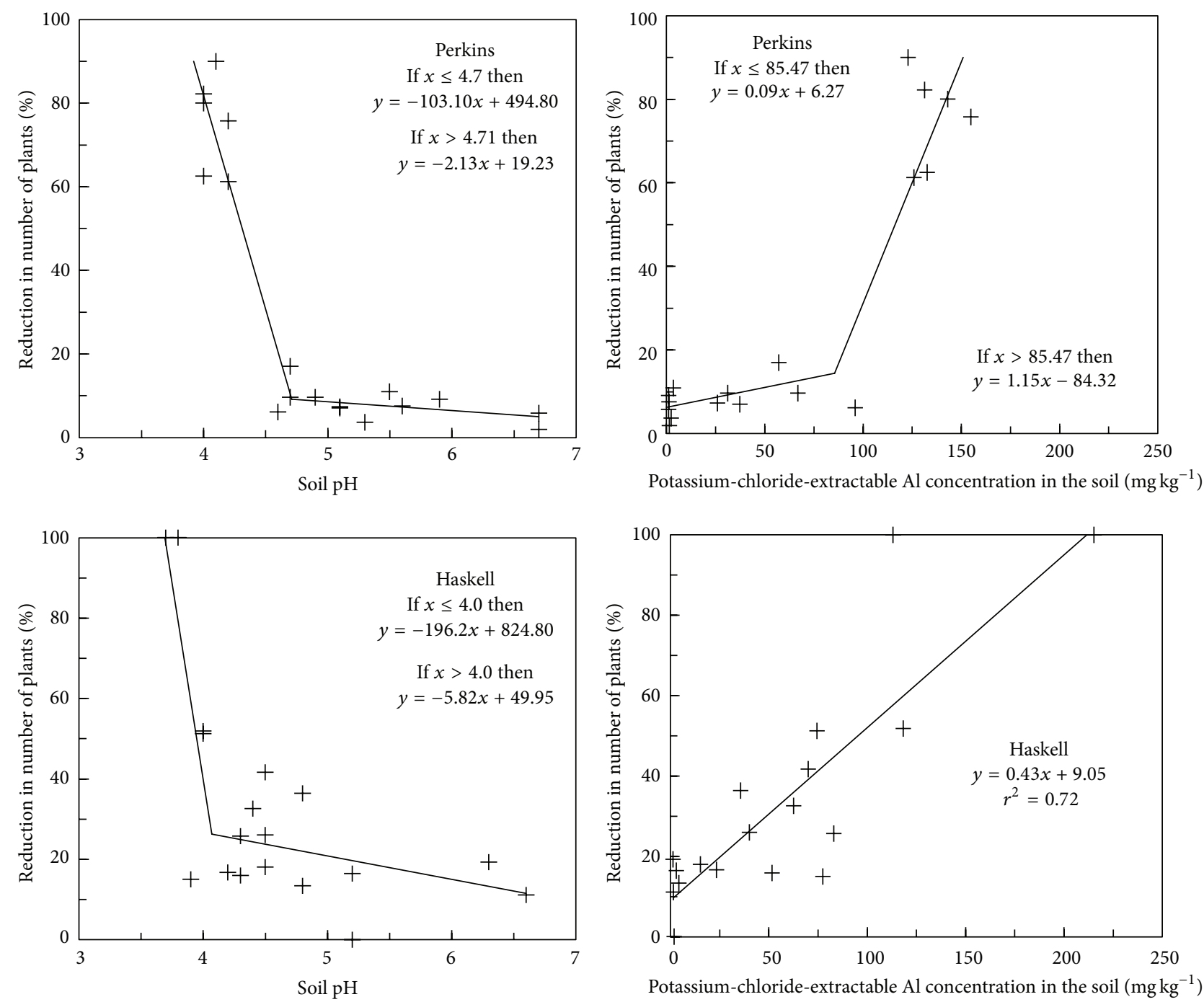

Potassium-chloride-extractable $\mathrm{Al}$ concentration in the soil $\left(\mathrm{mg} \mathrm{kg}^{-1}\right)$
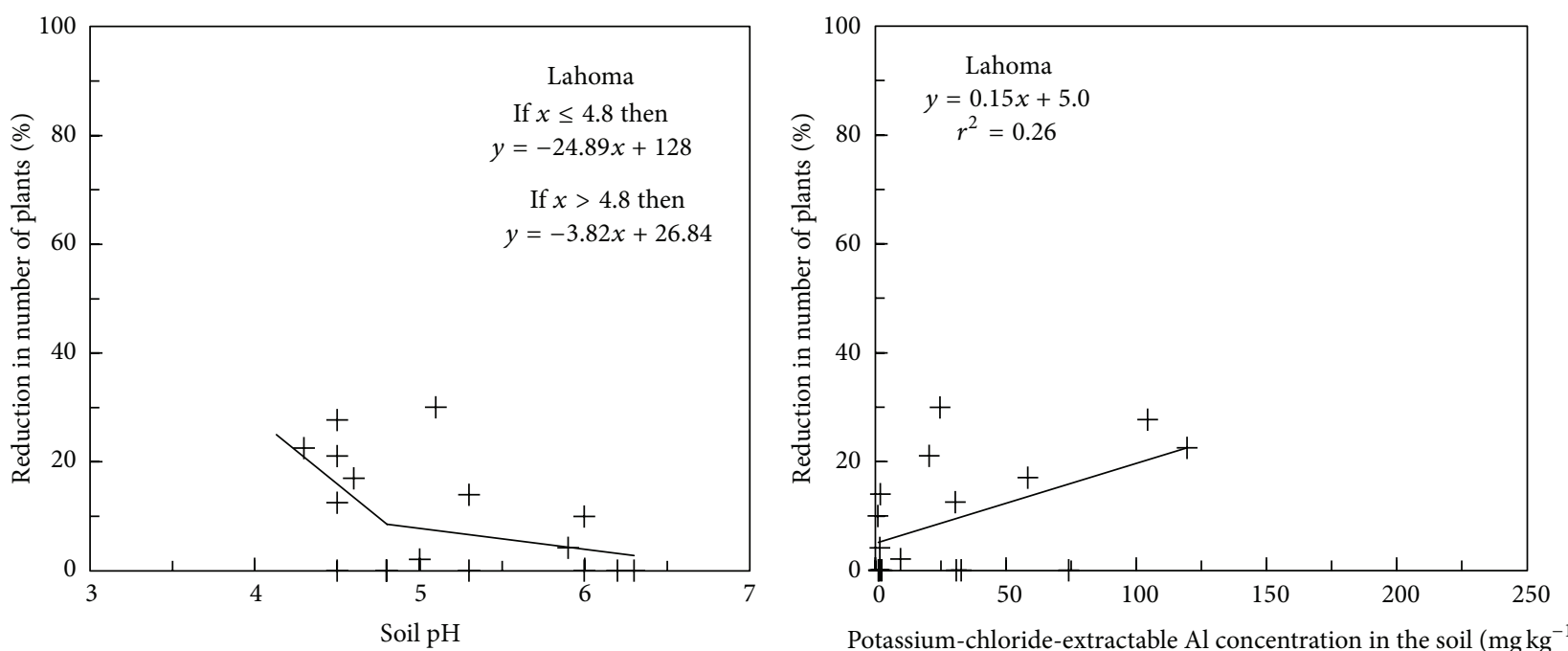

Potassium-chloride-extractable $\mathrm{Al}$ concentration in the soil $\left(\mathrm{mg} \mathrm{kg}^{-1}\right)$

Figure 4: Percent reduction in number of sunflower plants from emergence to harvest as a function of soil pH and potassium-chlorideextractable aluminum concentration $\left(\mathrm{mg} \mathrm{kg}^{-1}\right)$ in the soil at Perkins, Haskell, and Lahoma, Oklahoma, in 2010. 
extractable $\mathrm{Al}$ level may not induce $\mathrm{Al}$ toxicity symptoms in crops if the soil has adequate levels of exchangeable base cations $[17,33]$.

Sunflower growth, as measured by plant height and NDVI, was adversely affected by soil acidity and $\mathrm{Al}_{\mathrm{KCl}}$ concentration in the soil (Figures 5 and 6). The effects of soil $\mathrm{pH}$ in plant height and in NDVI followed very similar patterns. However, plant height was more sensitive to soil $\mathrm{pH}$ and to extractable Al than NDVI, with a broad range of plant height values across locations.

Plant height was significantly affected by soil $\mathrm{pH}$ at Perkins, resulting in low plant height values and steep response curve of plant height to soil $\mathrm{pH}$, ranging from approximately $5 \mathrm{~cm}$ to $25 \mathrm{~cm}$ (Figure 5). Plant height increased linearly with soil $\mathrm{pH}$ until $\mathrm{pH} 4.9$, where a plateau occurred. At Haskell, plant height ranged from $28 \mathrm{~cm}$ to $99 \mathrm{~cm}$, and although the values were not affected as they were at Perkins, a steep response curve of plant height to soil $\mathrm{pH}$ was also observed. Plant height increased linearly with the increase in soil $\mathrm{pH}$ until approximately a $\mathrm{pH}$ of 4.6 , where it reached a similar plateau observed at Perkins. At Lahoma, plant height ranged from $34 \mathrm{~cm}$ to $61 \mathrm{~cm}$, and, despite absolute values lower than the ones achieved at Haskell, the response curve of plant height as affected by soil $\mathrm{pH}$ was not as accentuated. A plateau was reached at approximately $\mathrm{pH}$ 5.7. Considering all sites, plant height plateaus were attained at soil $\mathrm{pH}$ of 4.6 or greater. The response of plant height to $\mathrm{Al}$ concentration followed a negative linear response, with greater $\mathrm{Al}_{\mathrm{KCl}}$ resulting in greater reduction in plant height (Figure 5).

Similar to the plant height, NDVI response to soil $\mathrm{pH}$ was well modeled by linear plateau functions, with a linear increase in NDVI as $\mathrm{pH}$ increased until approximately 5 , followed by a plateau with nearly constant NDVI (Figure 6). The breakpoints for NDVI, however, differed from those found for plant height, probably because NDVI is a function of whole plant health and growth status, correlated with several plant variables other than plant height (i.e., plant biomass, nitrogen concentration, and yield) [34]. The breakpoints resulting from the analysis of NDVI versus soil $\mathrm{pH}$ were generally lower than that resultant from plant height versus $\mathrm{pH}$, indicating that NDVI had reached stable (maximum) values at lower soil $\mathrm{pH}$ than did plant height. At Perkins, plateau occurred at a $\mathrm{pH}$ of 4.9; however, at Lahoma, the plateau was decreased from 5.7 to 5.2 and at Haskell from 4.6 to 4.2. The lower breakpoints found for NDVI as compared to plant height are probably function of other factors driving NDVI readings, such as biomass, fractional canopy cover, or nitrogen concentration, which were not measured in this study. Nonetheless, the NDVI data demonstrate the reduction in biomass and plant vigor of plants in the plots with low $\mathrm{pH}$ treatments as compared to the high $\mathrm{pH}$ plots. As low $\mathrm{pH}$ caused $\mathrm{Al}$ to be soluble in the soil solution, NDVI reading significantly decreased as the $\mathrm{Al}$ concentration increased, following a linear trend as did plant height. The decreasing trend of plant biomass and plant vigor in response to $\mathrm{Al}$ concentrations was more accentuated in Perkins and Haskell as compared to Lahoma, as relationships between NDVI and soil $\mathrm{Al}$ concentrations were not significant at the later site.
3.4. Relative Yield. The relationships between relative sunflower seed yield and soil $\mathrm{pH}$ are presented in Figure 7. Yield data from Haskell 2009 could not be analyzed due to intense bird damage and nonrepresentative sunflower seed yields and therefore data are not shown. Also, yield data were not presented for Perkins 2009 because germination was severely affected by flooding. Relative yield exhibited a positive response to increasing soil $\mathrm{pH}$ at different magnitudes based on locations and years, and nonlinear regression analysis generated yield plateaus for the four site-years analyzed for yields as function of soil $\mathrm{pH}$.

Relative yield and soil $\mathrm{pH}$ were highly correlated at Perkins $\left(r^{2}=0.94\right)$ and Haskell $\left(r^{2}=0.70\right)$ in the 2010 growing season, while yield response to soil acidity was not as strongly correlated at Lahoma in either of the years (Figure 7). At Perkins, nonlinear regression analysis generated a yield plateau at relative yield 0.88 and soil $\mathrm{pH}$ 5.0. This means that at $\mathrm{pH} 5.0$ yield losses were approximately $12 \%$. The regression equation obtained from the nonlinear regression analysis was solved to determine the soil $\mathrm{pH}$ at relative yield of 0.90 considering $10 \%$ yield loss. At $10 \%$ yield loss, the critical $\mathrm{pH}$ at Perkins was calculated as 5.1. Similar procedure was used to calculate critical soil $\mathrm{pH}$ for all locations, resulting in critical soil $\mathrm{pH}$ of 4.9 at Haskell. The slightly lower soil $\mathrm{pH}$ resulting in the 0.90 relative yields at Haskell as compared to Perkins may be a function of the higher $\mathrm{Al}_{\mathrm{KCl}}$ concentration at Perkins at similar soil pH levels (Figure 3). At Haskell $\mathrm{Al}_{\mathrm{KCl}}$ concentration was approximately $23.4 \mathrm{mg} \mathrm{kg}^{-1}$, and at Perkins $\mathrm{Al}_{\mathrm{KCl}}$ was $31.1 \mathrm{mg} \mathrm{kg}^{-1}$ in terms of corresponding critical soil $\mathrm{pH}$. Using information from Table 1, the approximate $\mathrm{Al}$ saturation of Haskell at $\mathrm{pH} 5.1$ is $27 \%$, whereas at Perkins, the $\mathrm{Al}$ saturation at $\mathrm{pH} 4.9$ is $31 \%$. Aluminum saturation may be the major cause of lower relative yields of 0.90 when compared to maximum yields. The presence of $\mathrm{Al}_{\mathrm{KCl}}$ per se may not induce crop $\mathrm{Al}$ toxicity in acid soils of Oklahoma $[17,18]$. The weaker relationship between relative sunflower seed yield and soil $\mathrm{pH}$ at Lahoma is also likely function of low $\mathrm{Al}$ saturation at this site. Due to the high base cation concentration in the Grant silt loam at Lahoma (Table 1), average $\mathrm{Al}$ saturation across the experiment was approximately $19 \%$, which did not significantly reduce yields to levels lower than 0.9 in the remaining sites of this study. At Lahoma, only four plots resulted in $\mathrm{Al}$ saturation greater than $20 \%$, indicating that the low $\mathrm{Al}$ saturation at this site was not enough to decrease yields significantly.

Relative seed yield as a function of $\mathrm{Al}_{\mathrm{KCl}}$ and $\mathrm{Al}$ saturation was significant in two out of three locations in 2010 (Figure 8). At Perkins, $\mathrm{Al}_{\mathrm{KCl}}$ concentration was calculated as $6.35 \mathrm{mg} \mathrm{kg}^{-1}$ when $10 \%$ yield loss was accounted. The same yield loss was calculated for $\mathrm{Al}$ saturation at $2 \%$. Negative linear relationship between relative yield and $\mathrm{Al}_{\mathrm{KCl}}$ and $\mathrm{Al}$ saturation was also found at Haskell, indicating that yield loss was associated with greater $\mathrm{Al}$ concentrations in the soil at both locations. For both the Teller fine-loamy at Perkins and the Taloka fine soil at Haskell, yield loss was greater than $60 \%$ when $\mathrm{Al}_{\mathrm{KCl}}$ in the soil was over $100 \mathrm{mg} \mathrm{kg}^{-1}$. Relative yield was significantly correlated neither to $\mathrm{Al}_{\mathrm{KCl}}$ nor to $\mathrm{Al}$ saturation at Lahoma, probably due to a greater effective 

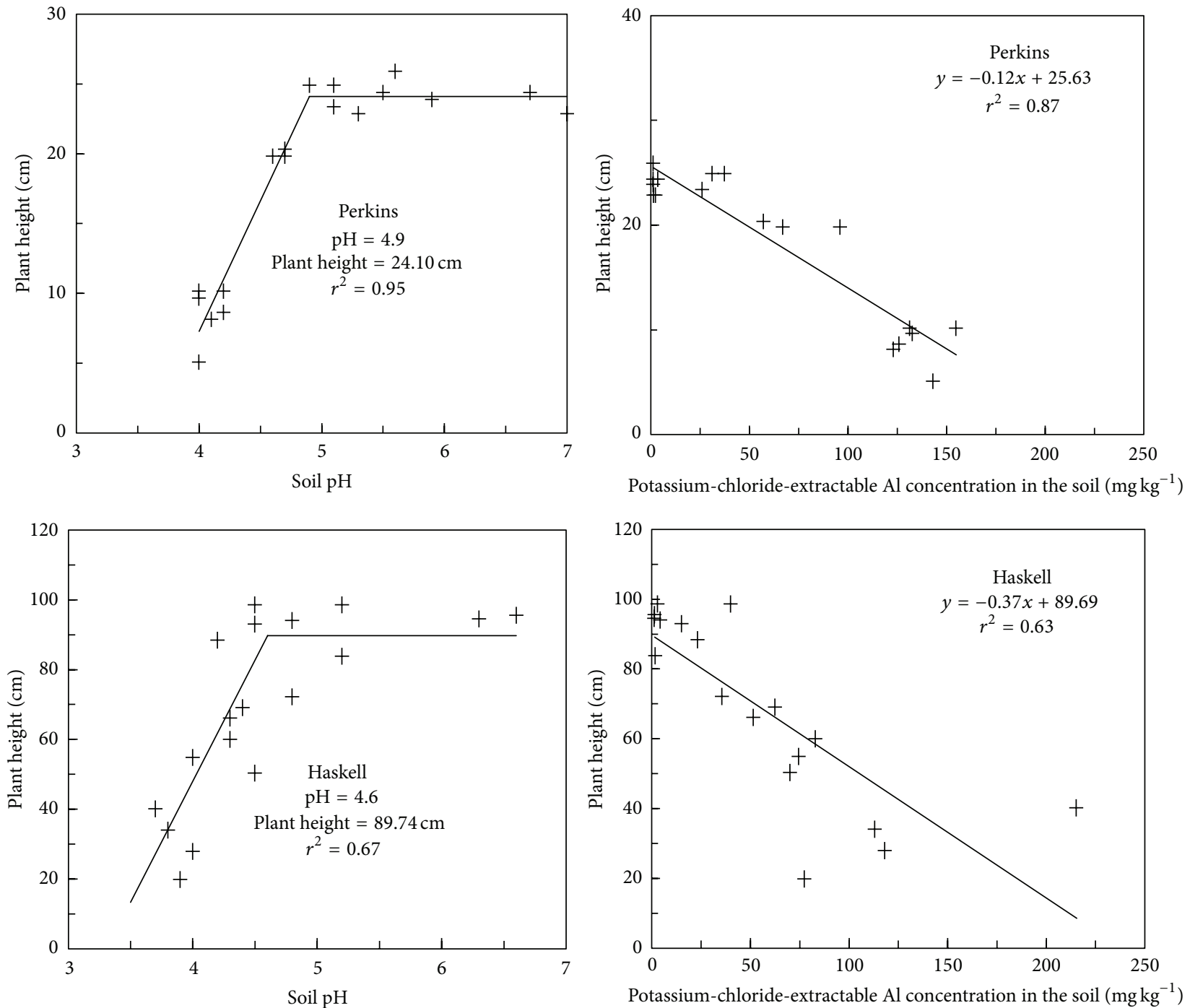

Potassium-chloride-extractable Al concentration in the soil $\left(\mathrm{mg} \mathrm{kg}^{-1}\right)$
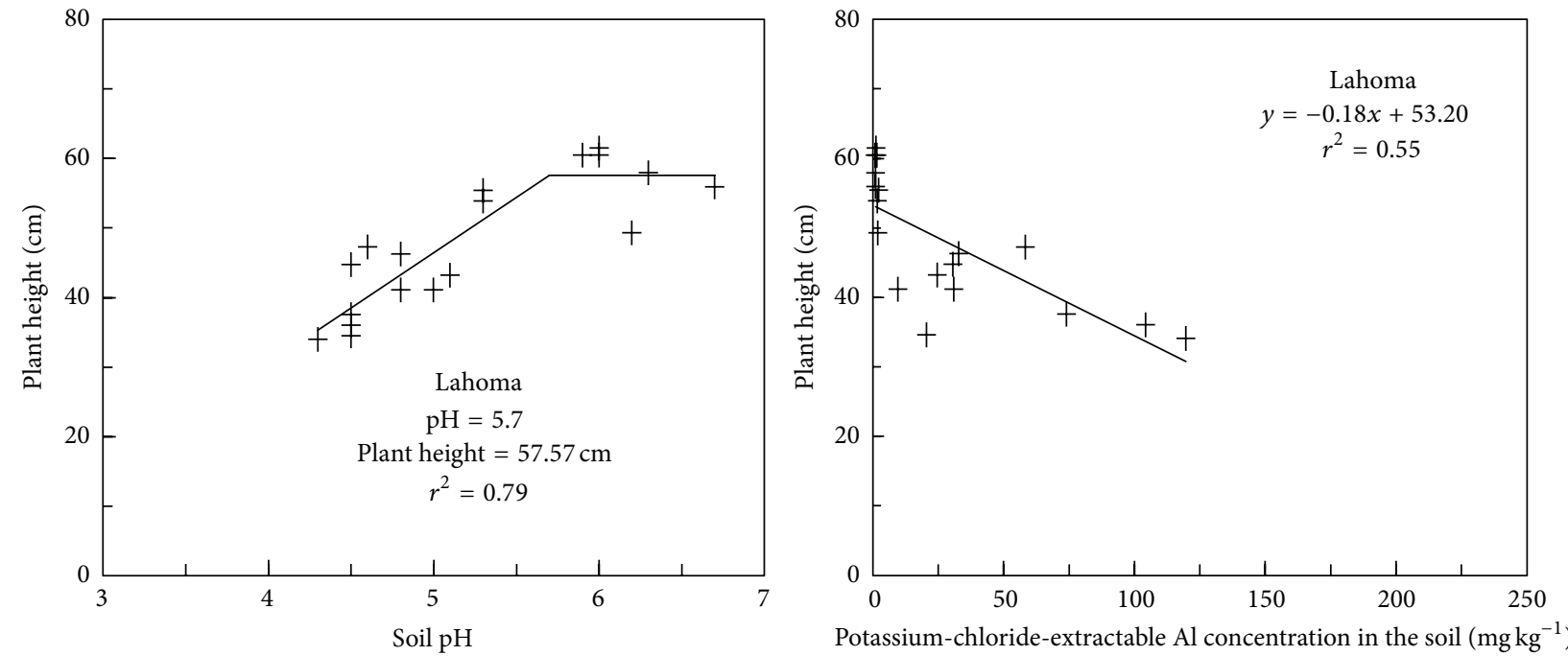

FIGURE 5: Sunflower plant height as a function of soil $\mathrm{pH}$ and potassium-chloride-extractable aluminum concentration ( $\mathrm{mg} \mathrm{kg}^{-1}$ ) in the soil at Perkins, Haskell, and Lahoma, Oklahoma, in 2010. 

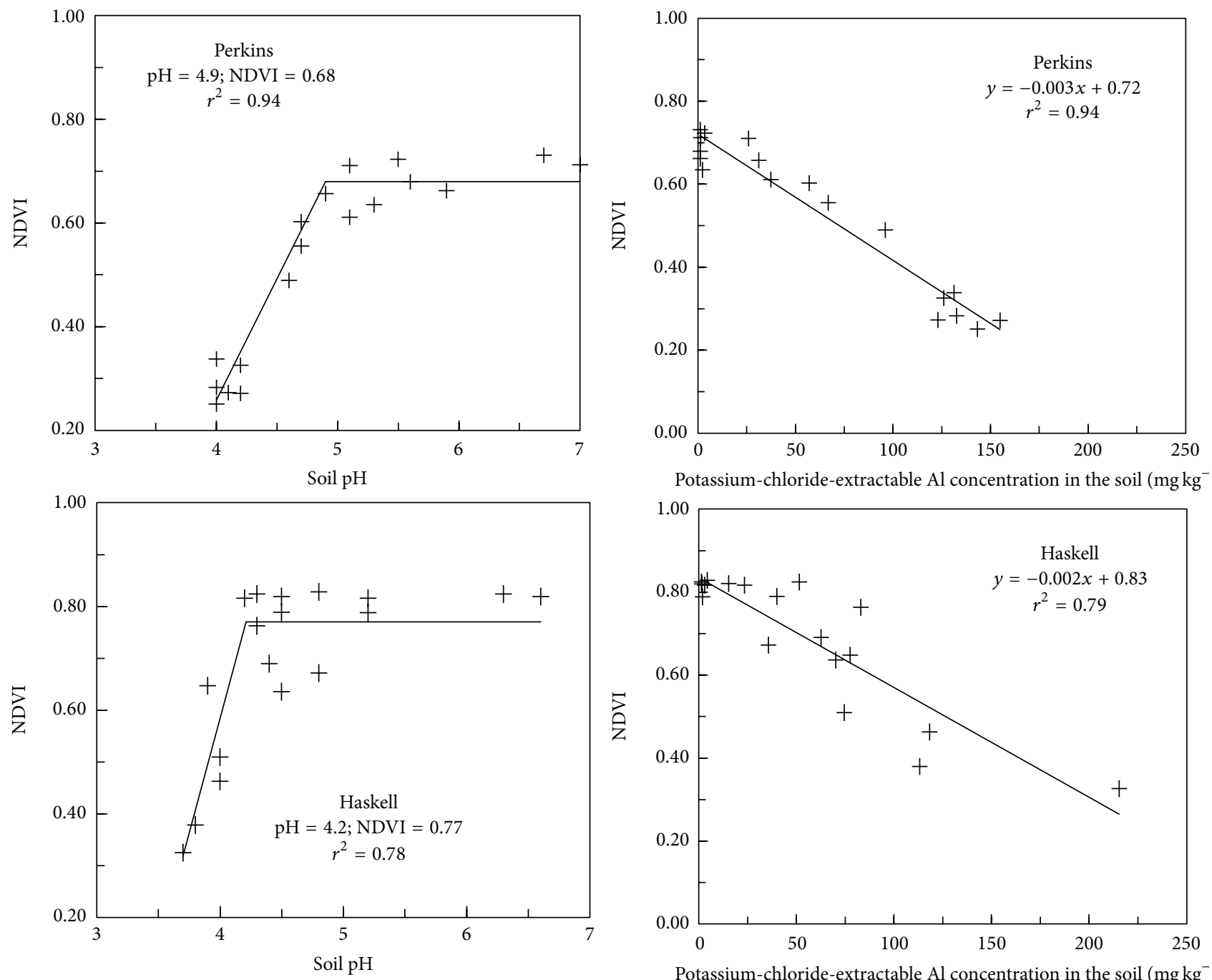

Potassium-chloride-extractable $\mathrm{Al}$ concentration in the soil $\left(\mathrm{mg} \mathrm{kg}^{-1}\right)$

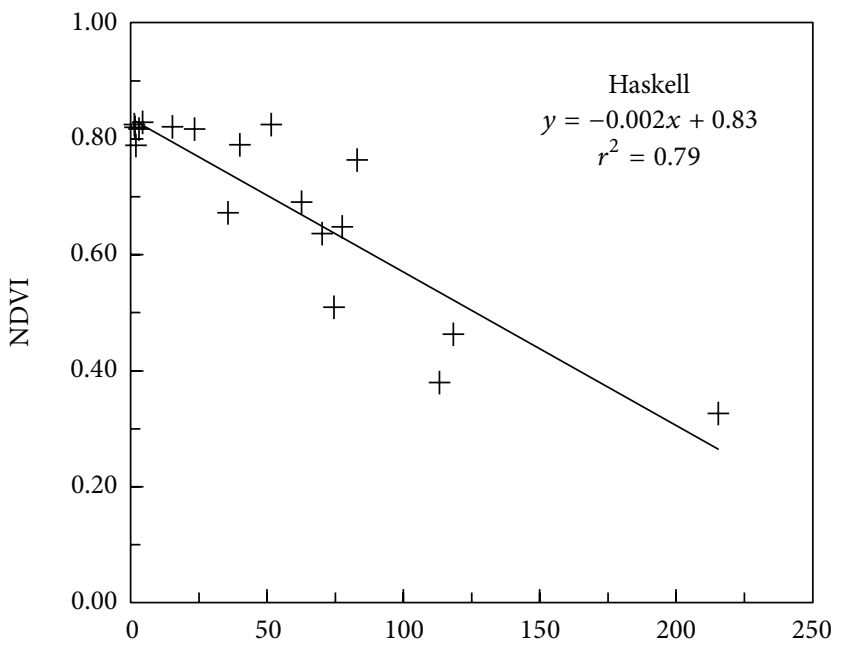

Potassium-chloride-extractable $\mathrm{Al}$ concentration in the soil $\left(\mathrm{mg} \mathrm{kg}^{-1}\right)$
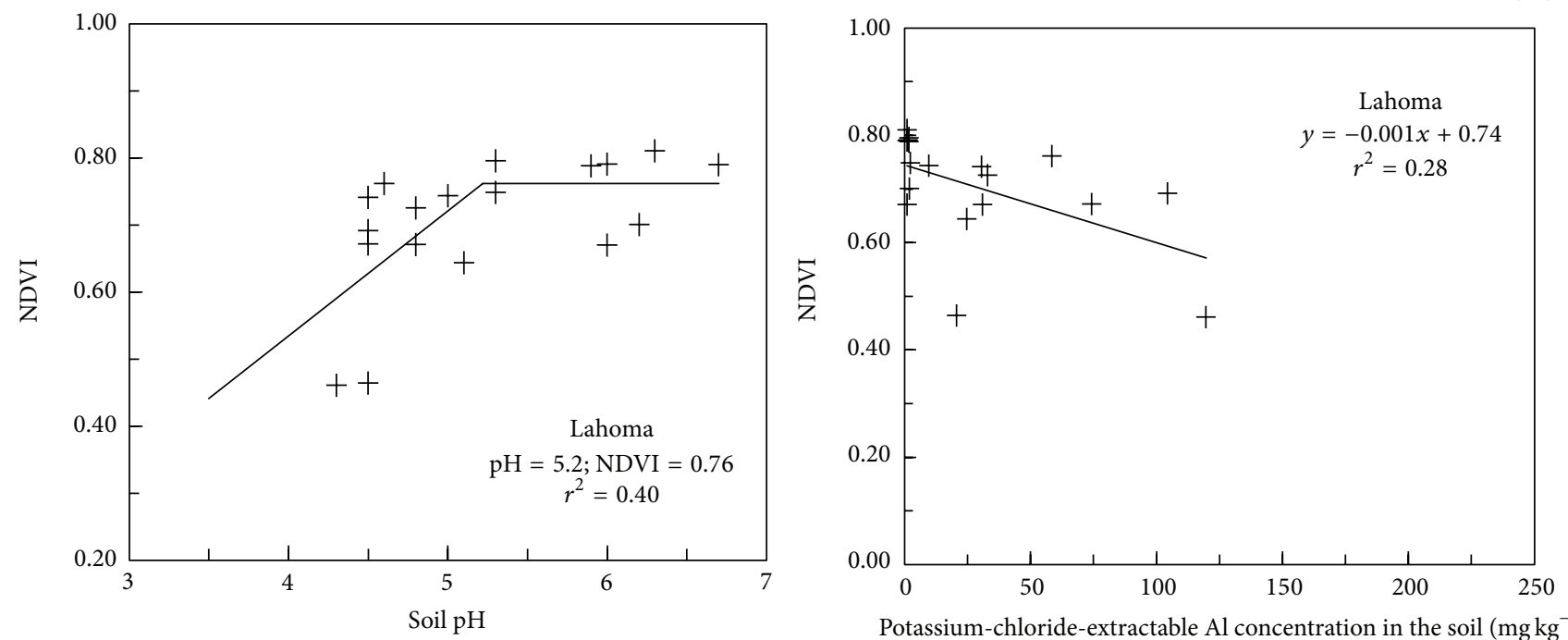

Potassium-chloride-extractable $\mathrm{Al}$ concentration in the soil $\left(\mathrm{mg} \mathrm{kg}^{-1}\right)$

FIGURE 6: Normalized Difference Vegetative Index (NDVI) as a function of soil $\mathrm{pH}$ and potassium-chloride-extractable aluminum concentration $\left(\mathrm{mg} \mathrm{kg}^{-1}\right)$ in the soil at Perkins, Haskell, and Lahoma, Oklahoma, in 2010. 

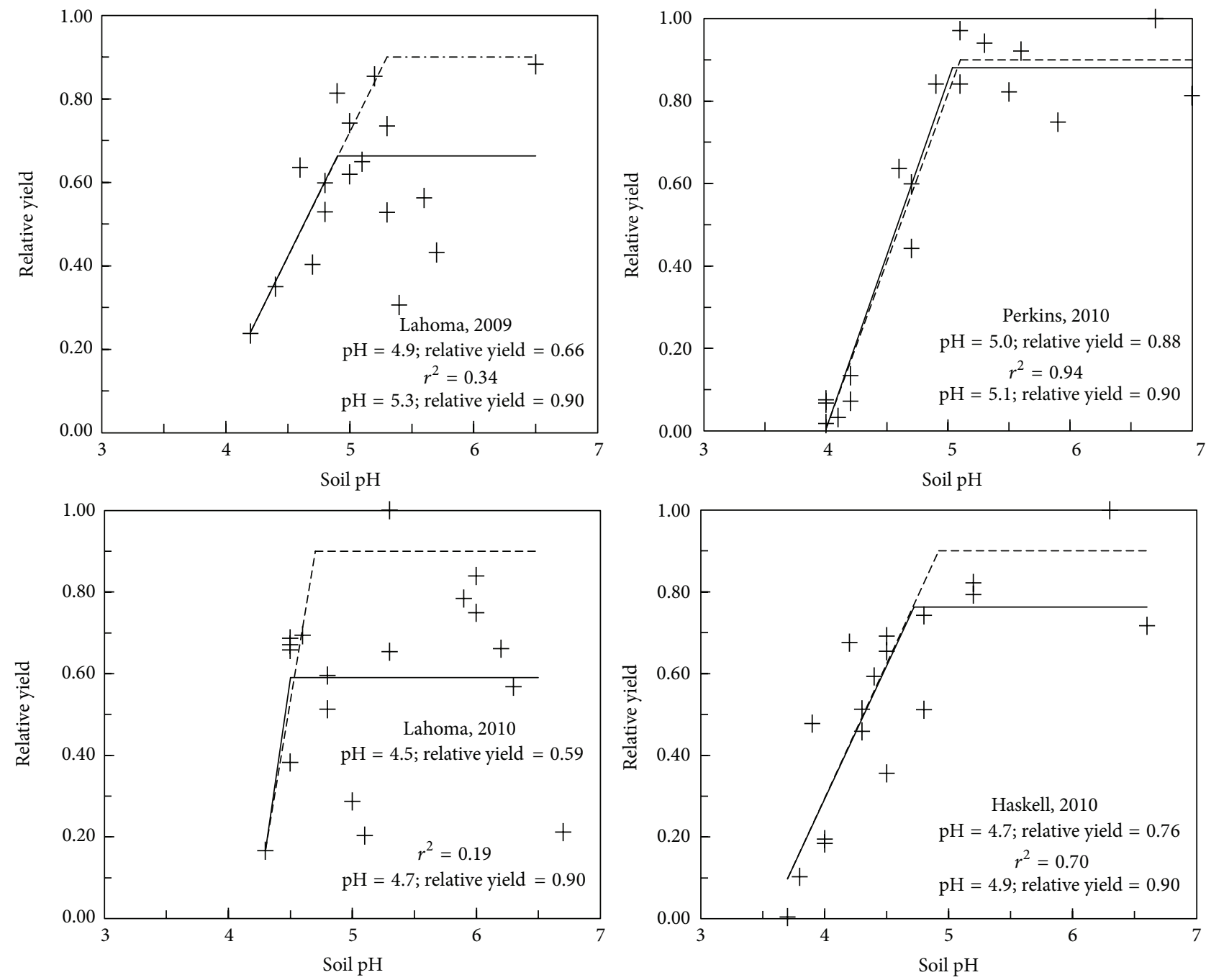

Figure 7: Relative seed yield of sunflower as a function of soil pH at Lahoma, Perkins, and Haskell, OK. Solid lines show where the yield plateau occurred. Broken lines mean yield plateau occurring at 0.90 with critical soil pH (2009 and 2010).

cation exchange capacity of the studied Grant Silt Loam, alleviating the consequences of the presence of $\mathrm{Al}_{\mathrm{KCl}}$.

\section{Conclusions}

Results from this research demonstrate that low soil $\mathrm{pH}$ and high concentration of $\mathrm{Al}_{\mathrm{KCl}}$ resulted in a significant reduction in sunflower growth and yield. Plant mortality, height, NDVI, and relative seed yield with potassium-chloride-extractable $\mathrm{Al}$ also showed significant negative relationships in most siteyears. Critical soil $\mathrm{pH}$ and $\mathrm{Al}_{\mathrm{KCl}}$ differed by soil types and years for all growth and yield parameters evaluated. At the Perkins site, Teller sandy loam, a plant loss of greater than $10 \%$ occurred at a $\mathrm{pH}$ of 4.7 and corresponding $\mathrm{Al}_{\mathrm{KCl}}$ level of $41 \mathrm{mg} \mathrm{kg}^{-1}$. Both plant height and NDVI were maximized at a soil $\mathrm{pH}$ of 4.9. At Perkins the relative yields values fell below the point of $90 \%$ at a soil $\mathrm{pH}$ of 5.1 . At the Haskell location, Taloka silt loam, plant stand was significantly impacted at a $\mathrm{pH}$ of 4.0 and negatively linearly correlated with $\mathrm{Al}_{\mathrm{KCl}}$ level with no critical point being found. A soil $\mathrm{pH}$ of 4.6 and 4.2 was found for plant height and NDVI, respectively. The linear plateau model of seed yield identified a 4.7 soil $\mathrm{pH}$ as the critical level. At the final location, Lahoma a Grant silt loam, $10 \%$ plant loss occurred at a soil $\mathrm{pH}$ of 4.8. Analysis of plant vigor measurements, plant height, and NDVI resulted in critical levels of 5.7 and 5.2, respectively. Yield, however, plateaued at a soil pH of 4.9 and 4.5 in 2009 and 2010, respectively. Based on the findings of this research the agronomic optimum level of soil $\mathrm{pH}$ for sunflower production is at a level of 5.0 and above. Given the relative low $\mathrm{pH}$ in which sunflower yield resulted in $10 \%$ losses $(4.7$ to 5.3), the crop is a very promising summer rotation to winter wheat in fields where the remediation of soil acidity via application of lime is not economically feasible. Comparing critical soil $\mathrm{pH}$ for some other rotational crops in Oklahoma, such as grain sorghum ( $\mathrm{pH}$ 5.4) [25], canola $(\mathrm{pH}$ 5.8) [13], and soybean ( $\mathrm{pH} 5.5$ to 7.0) [16], sunflower is a better choice in acidic conditions as rotational crop with winter wheat as the critical $\mathrm{pH}$ values are less than the above mentioned crops. 

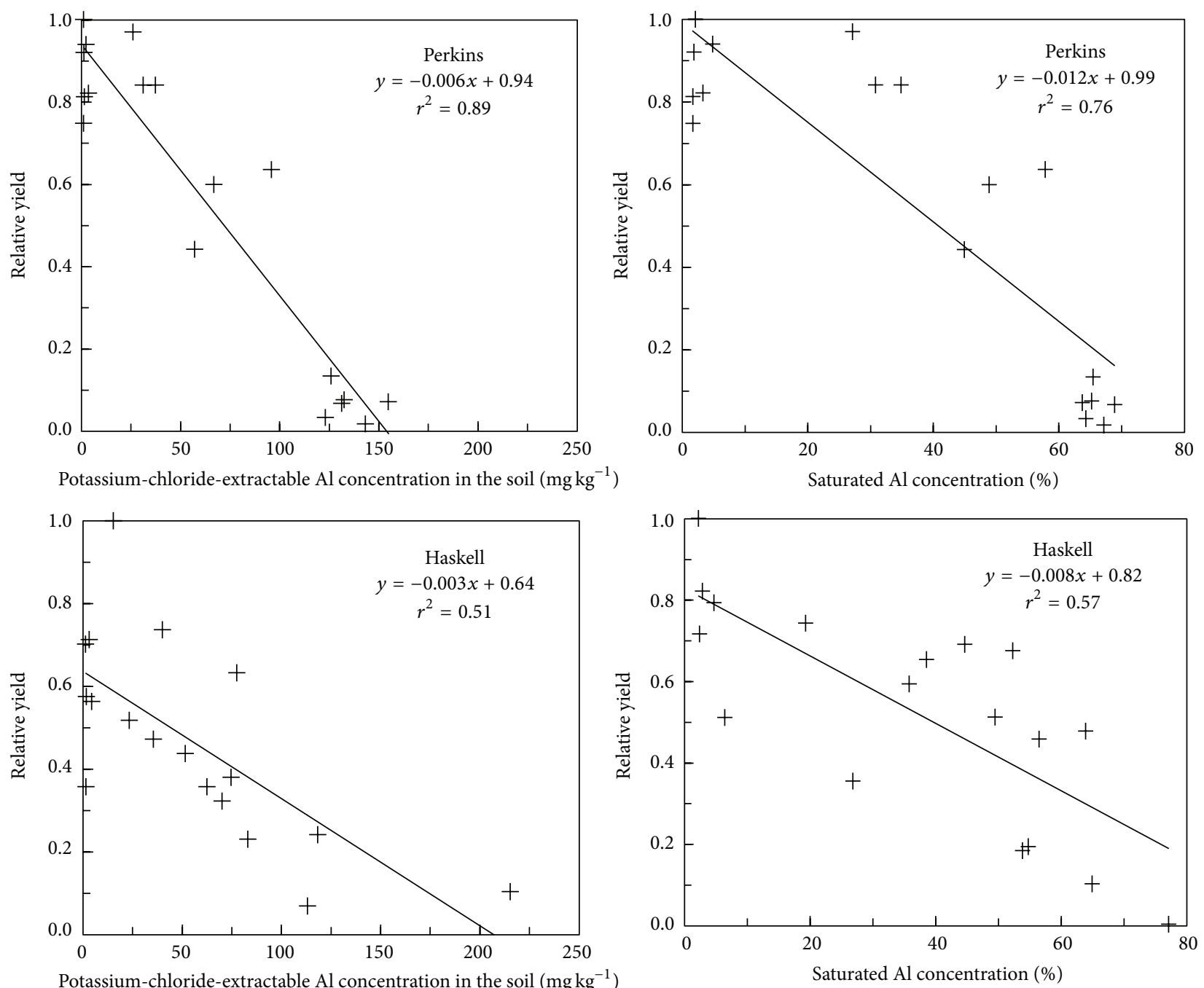

Potassium-chloride-extractable $\mathrm{Al}$ concentration in the soil $\left(\mathrm{mg} \mathrm{kg}^{-1}\right)$
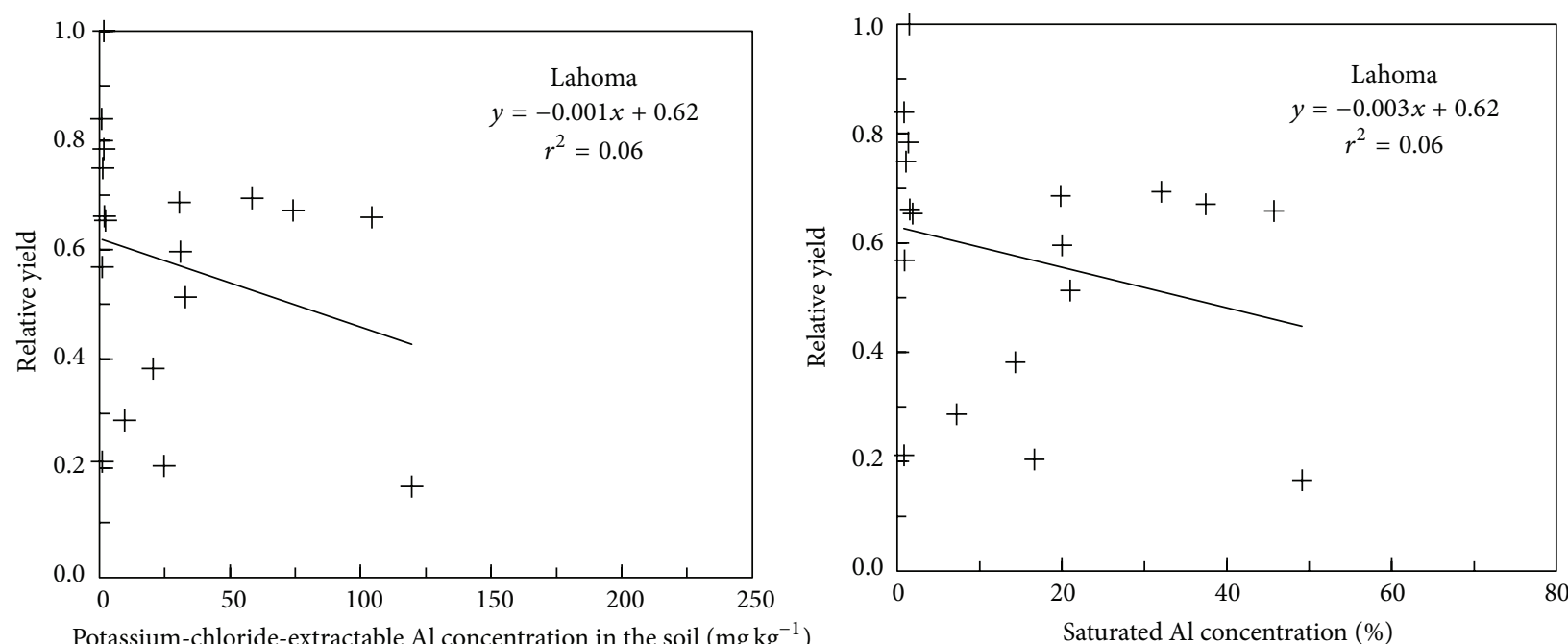

FIGURE 8: Relative sunflower seed yield as a function of potassium-chloride-extractable aluminum concentration (mg kg $\left.{ }^{-1}\right)$ and aluminum saturation (\%) in the soil at Perkins, Haskell, and Lahoma, Oklahoma, in 2010. 


\section{Conflict of Interests}

The authors declare that there is no conflict of interests regarding the publication of this paper.

\section{References}

[1] J. Edwards, F. Epplin, B. Hunger et al., "No-till wheat production in Oklahoma," Oklahoma Cooperative Extension Service Fact Sheet 2132, Oklahoma State University, Stillwater, Okla, USA, 2006.

[2] G. M. Torres, R. P. Lollato, and T. E. Ochsner, "Comparison of drought probability assessments based on atmospheric water deficit and soil water deficit," Agronomy Journal, vol. 105, no. 2, pp. 428-436, 2013.

[3] P. E. Fixen, "Soil test levels in North America: summary update," Better Crops, vol. 82, no. 4, pp. 16-18, 1998.

[4] H. Zhang and B. McCray, "Oklahoma agricultural soil test summary 2004-2008," Oklahoma Cooperative Extension Service Current Report 2259, Oklahoma State University, Stillwater, Okla, USA, 2008.

[5] R. L. Blevins, G. W. Thomas, and P. L. Cornelius, "Influence of no-tillage and nitrogen fertilization on certain soil properties after 5 years of continuous corn," Agronomy Journal, vol. 10, no. 3, pp. 383-386, 1977.

[6] H. L. Bohn, B. L. McNeal, and G. A. O’Connor, Soil Chemistry, John Wiley \& Sons, New York, NY, USA, 3rd edition, 2001.

[7] J. L. Schroder, H. Zhang, K. Girma, W. R. Raun, C. J. Penn, and M. E. Payton, "Soil acidification from long-term use of nitrogen fertilizers on winter wheat," Soil Science Society of America Journal, vol. 75, no. 3, pp. 957-964, 2011.

[8] J. F. Power and R. Prasad, Soil Fertility Management for Sustainable Agriculture, CRC Press, Boca Raton, Fla, USA, 1997.

[9] D. F. Garvin and B. F. Carver, "Role of genotype in tolerance to acidity and aluminum toxicity," in Handbook of Soil Acidity, Z. Rengel, Ed., pp. 387-406, Marcel Dekker, New York, NY, USA, 2003.

[10] "United States Department of Agriculture, National Agricultural Statistics Service," July 2012, http://www.nass.usda.gov/ Statistics_by_State/Oklahoma/Publications/County_Estimates/ index.asp.

[11] E. Delhaize and P. R. Ryan, "Aluminum toxicity and tolerance in plants," Plant Physiology, vol. 107, no. 2, pp. 315-321, 1995.

[12] C. Tang, Z. Rengel, E. Diatloff, and C. Gazey, "Responses of wheat and barley to liming on a sandy soil with subsoil acidity," Field Crops Research, vol. 80, no. 3, pp. 235-244, 2003.

[13] J. Lofton, C. B. Godsey, and H. Zhang, "Determining aluminum tolerance and critical soil $\mathrm{pH}$ for winter canola production for acidic soils in temperate regions," Agronomy Journal, vol. 102, no. 1, pp. 327-332, 2010.

[14] S. U. Wallace and I. C. Anderson, "Aluminum toxicity and DNA synthesis in wheat roots," Agronomy Journal, vol. 76, no. 1, pp. 5-8, 1982.

[15] M. A. Pavan, F. T. Bingham, and P. F. Pratt, "Toxicity of aluminium to coffee in ultisols and oxisols amended with $\mathrm{CaCO}_{3}$, $\mathrm{MgCO}_{3}$, and $\mathrm{CaSO}_{4} \cdot 2 \mathrm{H}_{2} \mathrm{O}$," Soil Science Society of America Journal, vol. 46, no. 6, pp. 1210-1207, 1982.

[16] H. Zhang and B. Raun, Oklahoma Soil Fertility Handbook, Department of Plant and Soil Sciences, Oklahoma State University, Stillwater, Okla, USA, 6th edition, 2006.
[17] R. P. Lollato, J. T. Edwards, and H. Zhang, "Effect of alternative soil acidity amelioration strategies on soil $\mathrm{pH}$ distribution and wheat agronomic response," Soil Science Society of America Journal, vol. 77, no. 5, pp. 1831-1841, 2013.

[18] S. Kaitibie, F. M. Epplin, E. G. Krenzer Jr., and H. Zhang, "Economics of lime and phosphorus application for dual-purpose winter wheat production in low-pH soils," Agronomy Journal, vol. 94, no. 5, pp. 1139-1145, 2002.

[19] D. R. Berglund, Sunflower Production, North Dakota Agricultural Experiment Station and North Dakota State University Extension Service Extension Publication A-1331 (EB-25 Revised), North Dakota State University, Fargo, ND, USA, 2007.

[20] S. K. Kariuki, H. Zhang, J. L. Schroder et al., "Hard red winter wheat cultivar responses to a $\mathrm{pH}$ and aluminum concentration gradient," Agronomy Journal, vol. 99, no. 1, pp. 88-98, 2007.

[21] J. T. Sims, "Lime requirement," in Methods of Soil Analysis, Part 3-Chemical Methods, D. L. Sparks, Ed., pp. 491-515, American Society of Agronomy, Soil Science Society of America, Madison, Wis, USA, 1st edition, 1996.

[22] F. J. Sikora, "A buffer that mimics the smp buffer for determining lime requirement of soil," Soil Science Society of America Journal, vol. 70, no. 2, pp. 474-486, 2006.

[23] A. Mehlich, "Mehlich 3 soil test extractant: a modification of Mehlich 2 extractant," Communications in Soil Science \& Plant Analysis, vol. 15, no. 12, pp. 1409-1416, 1984.

[24] P. N. Soltanpour, G. W. Johnson, S. M. Workman, J. B. Jones Jr., and R. O. Miller, "Inductively coupled plasma emission spectrometry and inductively coupled plasma-mass spectrometry," in Methods of Soil Analysis, Part 3-Chemical Methods, D. L. Sparks, A. L. Page, P. A. Helmke et al., Eds., pp. 91-139, American Society of Agronomy, Soil Science Society of America, Madison, Wis, USA, 1st edition, 1996.

[25] K. Butchee, D. B. Arnall, A. Sutradhar, C. Godsey, H. Zhang, and C. Penn, "Determining critical soil $\mathrm{pH}$ for grain sorghum production," International Journal of Agronomy, vol. 2012, Article ID 130254, 6 pages, 2012.

[26] Y. Lan, H. Zhang, R. Lacey, W. C. Hoffmann, and W. Wu, "Development of an integrated sensor and instrumentation system for measuring crop conditions," Agricultural Engineering International: The CIGR Journal, vol. 11, article IT 081115.

[27] P. M. Hansen and J. K. Schjoerring, "Reflectance measurement of canopy biomass and nitrogen status in wheat crops using normalized difference vegetation indices and partial least squares regression," Remote Sensing of Environment, vol. 86, no. 4, pp. 542-553, 2003.

[28] M. E. Sumner and W. P. Miller, "Cation exchange capacity and exchange coefficients," in Methods of Soil Analysis, Part 3-Chemical Methods, D. L. Sparks, A. L. Page, P. A. Helmke et al., Eds., pp. 1201-1253, American Society of Agronomy, Soil Science Society of America, Madison, Wis, USA, 1st edition, 1996.

[29] F. Gray and M. H. Roozitalab, Benchmark and Key Soils of Oklahoma: A Modern Classification System, Oklahoma State University, Agricultural Experiment Station, Stillwater, Okla, USA, 1976.

[30] K. A. McVay, D. E. Radcliffe, and W. L. Hargrove, "Winter legumes effects on soil properties and nitrogen fertilizer requirements," Soil Science Society of America Journal, vol. 53, pp. 1856-1862, 1989.

[31] P. A. Moore and D. R. Edwards, "Long-term effects of poultry litter, alum-treated litter, and ammonium nitrate on phosphorus availability in soils," Journal of Environmental Quality, vol. 36, no. 1, pp. 163-174, 2007. 
[32] J. G. Warren, S. B. Phillips, G. L. Mullins, D. Keahey, and C. J. Penn, "Environmental and production consequences of using alum-amended poultry litter as a nutrient source for corn," Journal of Environmental Quality, vol. 35, no. 1, pp. 172-182, 2006.

[33] J. P. Johnson Jr., B. F. Carver, and V. C. Baligar, "Productivity in great plains acid soils of wheat genotypes selected for aluminium tolerance," Plant and Soil, vol. 188, no. 1, pp. 101-106, 1997.

[34] B. Govaerts and N. Verhulst, The Normalized Difference Vegetation Index (NDVI) Greenseeker (TM) Handheld Sensor: Toward the Integrated Evaluation of Crop Management. Part A: Concepts and Case Studies, CIMMYT, Mexico City, Mexico, 2010. 


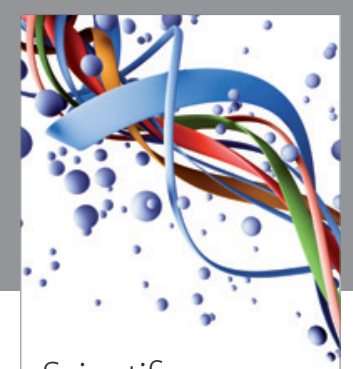

Scientifica
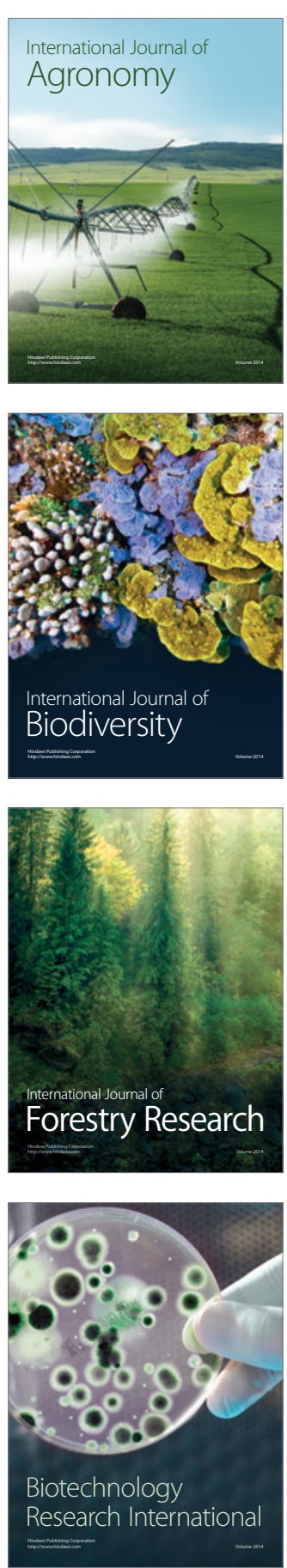
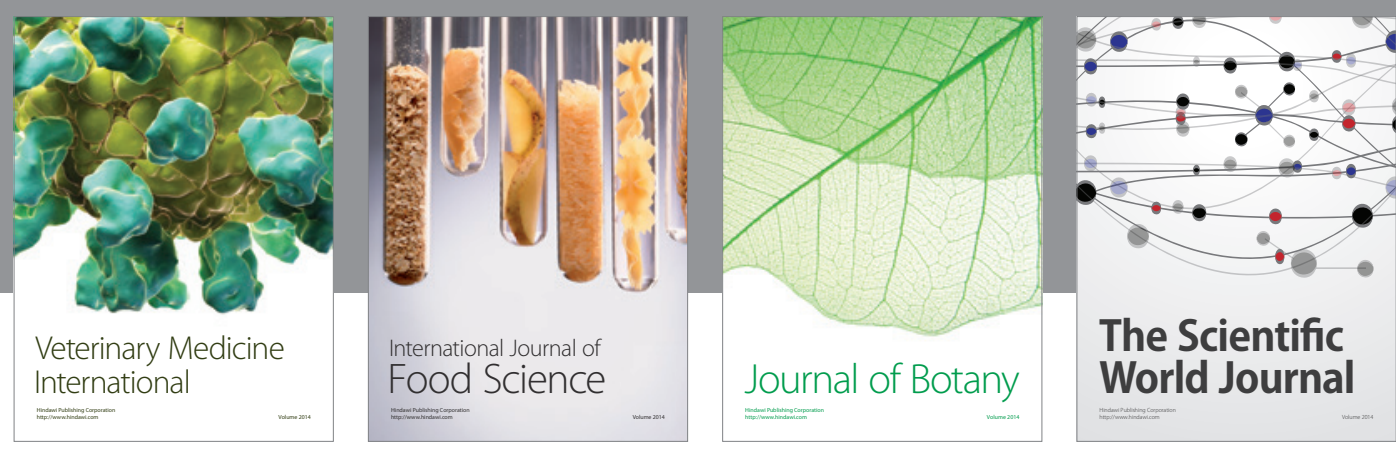

The Scientific World Journal
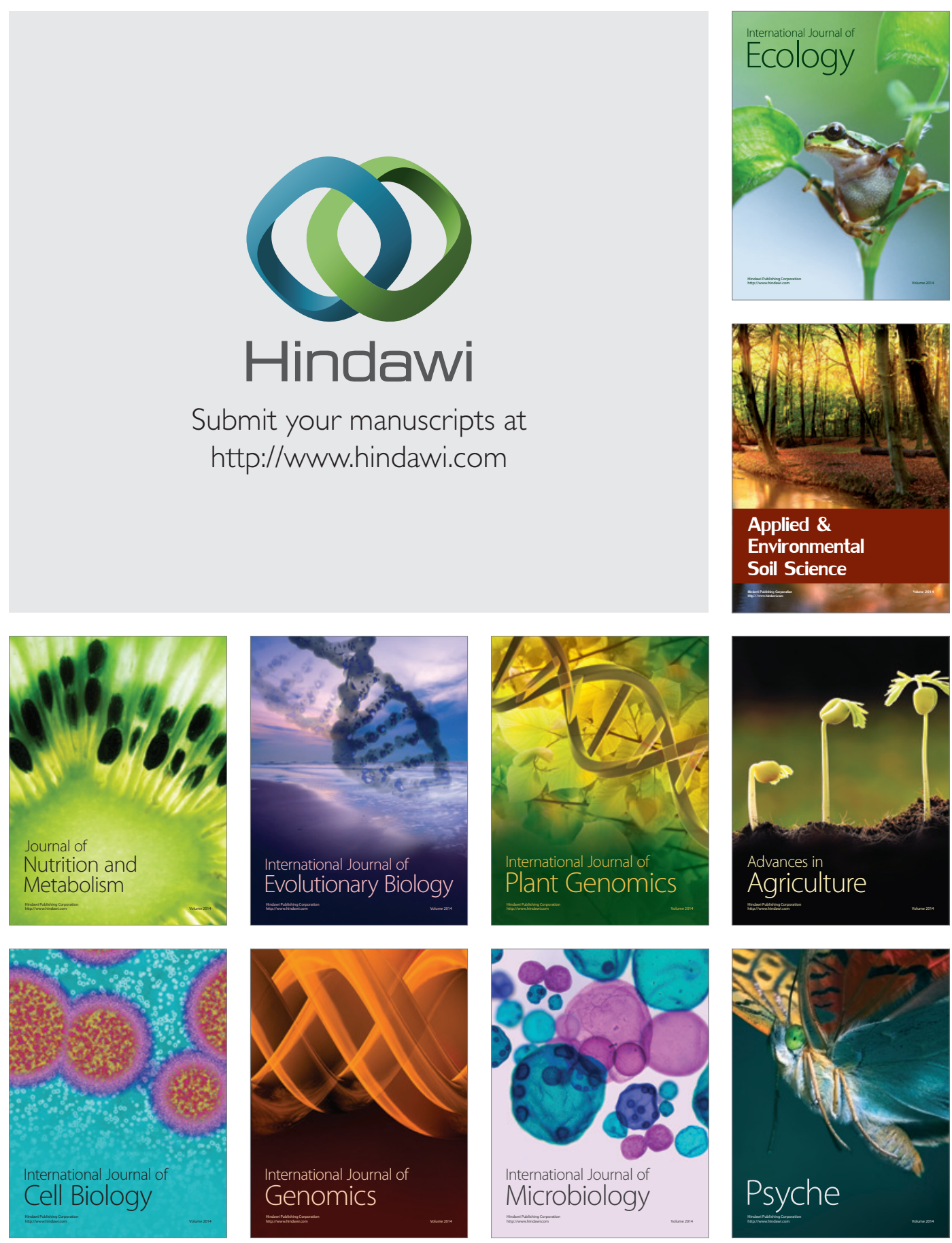